\title{
Storage in a Non-Villa Landscape: the Batavian Countryside
}

\author{
Stéphane Martin
}

The part of the Netherlands lying south of the Rhine corresponded roughly, in the Roman period, to the civitas Batavorum (Fig. 6.1). ${ }^{1}$ This whole area came under Roman domination after the Gallic Wars in the 50s BCE. From around 20 BCE, large numbers of Roman soldiers were stationed in and around Nijmegen and, from the 40s CE onwards, along the Rhine down to the North Sea (see Polak and Kooistra 2013 for a historical and archaeological overview of the early Roman period). Both military and civilian sites have been the subject of extensive research; as elsewhere in Europe, rescue archaeology has considerably increased the available data. Furthermore, the wet climate and subsoil of the region have made possible a substantial number of palaeobotanical studies. The Batavian area thus appears particularly suited to a study of the provisioning of the Roman army and of its impact on the surrounding countryside.

It is remarkable that in spite of the heavy influx of military personnel and of the creation of Nijmegen/Oppidum Batavorum and other smaller urban centres that marked the beginning of urbanization in the region, the occupation pattern of the countryside did not differ much from the pattern known in the Iron Age (Willems and Enckevort 2009, 81-94, largely based on Willems 1986b and focused on the region around Nijmegen; Vossen 2007, 37-40, with a broader scope. Occupation ceased almost everywhere in the late third century: Heeren 2015). Only from the late first century CE onwards was there a moderate increase in the number of settlements. Most notably, there was very strong continuity in the architectural tradition; stone was extremely rare and villae were almost completely absent: this is the "non-villa landscape" described by N. Roymans (1996).

1 Originally, it probably extended from the territory of Nijmegen in the east, to the North Sea in the west; at a later date (mid or late first century $\mathrm{CE}$ ?), the western part became the civitas Cannenefatium (on this complicated question, see Raepsaet and Raepsaet-Charlier 2013, 213-18; I leave out the problem of the civitas Frisiavonum since no site from this region is discussed here). Though the focus of this paper is on the eastern part of this area (Batavians stricto sensu), I will also take up some examples from the western part, as the countryside of both civitates displayed similar trends. 
The continuing tradition of indigenous settlement and the lack of villae have been generally taken as a sign that crop husbandry, if not agrarian production on the whole, was still low in the Roman period, and that most of the foodstuff needed by the army and the city-dwellers was imported, consolidating the general impression of a peripheral region in the Roman empire. This impression is consistent with the lack of good agricultural land outside of the fertile riverine area: settlements were concentrated there and their numbers decreased markedly in peat and sandy areas (see van Dinter 2013, Appendix 1, and Polak and Kooistra 2013 for palaeogeographic maps of the region). The presence of cereals not grown in the region at various military sites, as well as the boat loaded with grain found in Woerden and dated by dendrochronology to the last quarter of the second century CE, also lend support to the idea of continuing imports throughout the Roman period (Kooistra 2009, 2012; on Woerden, Pals and Hakbijl 1992 [carpology]; Haalebos 1996 [archaeology and dendrochronology]).

However, this view has been challenged in recent years by the "Sustainable Frontier" project (see Polak and Kooistra 2013 for a general presentation). Research carried out in this framework showed that the carrying capacity of the region was higher than previously thought. Most notably, in a paper published in 2009 in the Journal of Roman Archaeology (JRA) and thus disseminated to a wide audience, Maaike Groot, Stijn Heeren, Laura Kooistra and Wouter Vos defended the idea that during the Mid Roman period (from the end of the first to the end of the third centuries $\mathrm{CE}$ ), the Kromme Rijn region was indeed able to produce agrarian surpluses, both of animals and of cereals, in quantities not to be overestimated but still sufficient for peasants to participate substantially in a market economy (Groot et al. 20o9; focused on animal husbandry, Groot 2016 sticks to this general framework).

In reaching its conclusions, the paper combines archaeological, archaeobotanical and archaeozoological evidence from two fully excavated and published sites from the Kromme Rijn area (around Utrecht), namely Tiel "Passewaaij" (cat. 312) and Wijk bij Duurstede "De Horden" (cat. 313), taken as representative of the overall situation. The existence of surpluses is argued for on qualitative and quantitative grounds. Qualitative arguments stem from archaeobotanical and -zoological data, showing specialization in animal husbandry but not in cereal cultivation. The quantitative assessment comes from the comparison of the protein requirements of the inhabitants, whose number is deduced from the number of houses per settlement and per phase, with the production capacity of each settlement, reconstructed from the size of stalls and granaries. Furthermore, some granaries also changed in shape, exhibiting more "Roman" features. The intensification in cereal production is therefore 


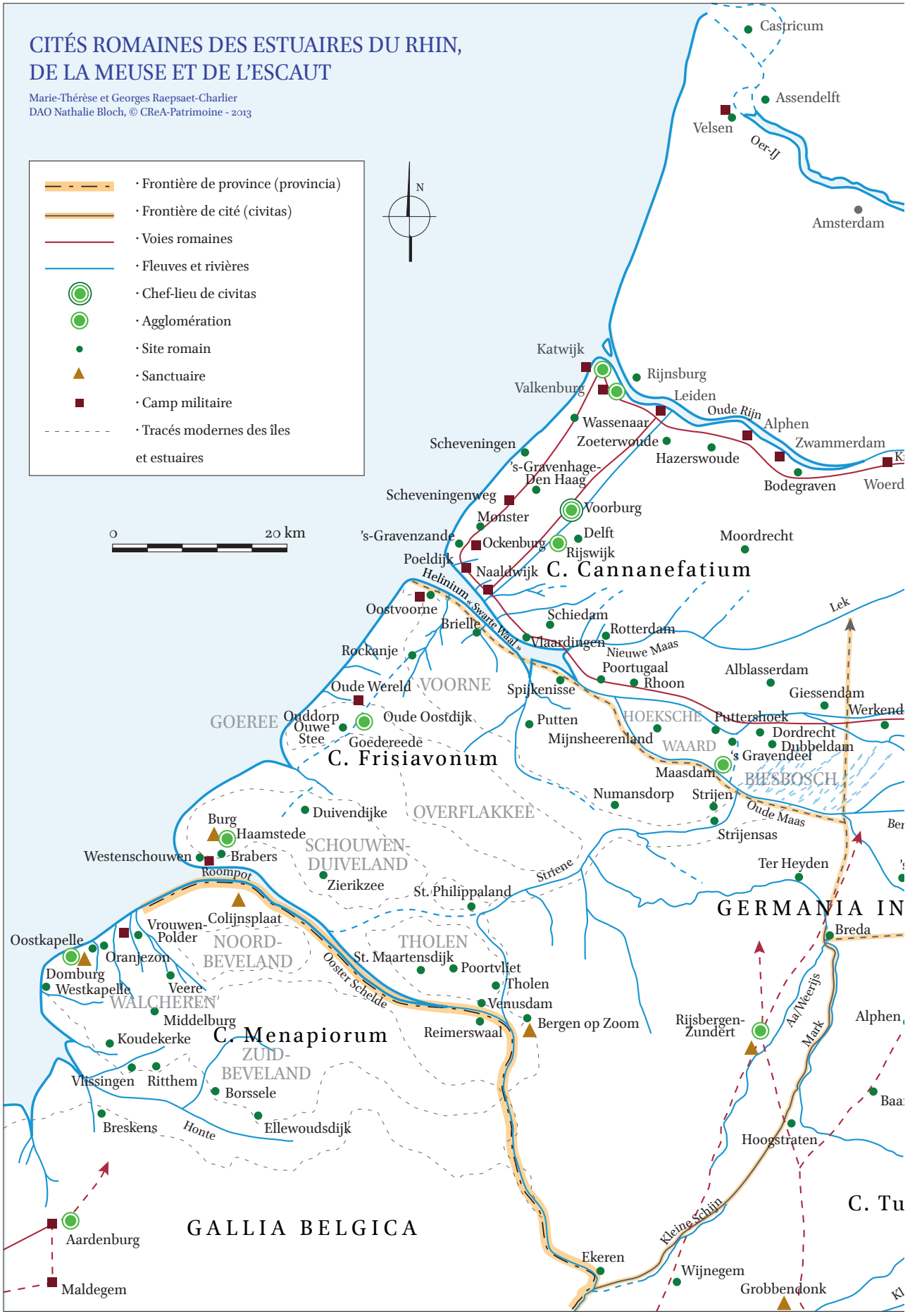




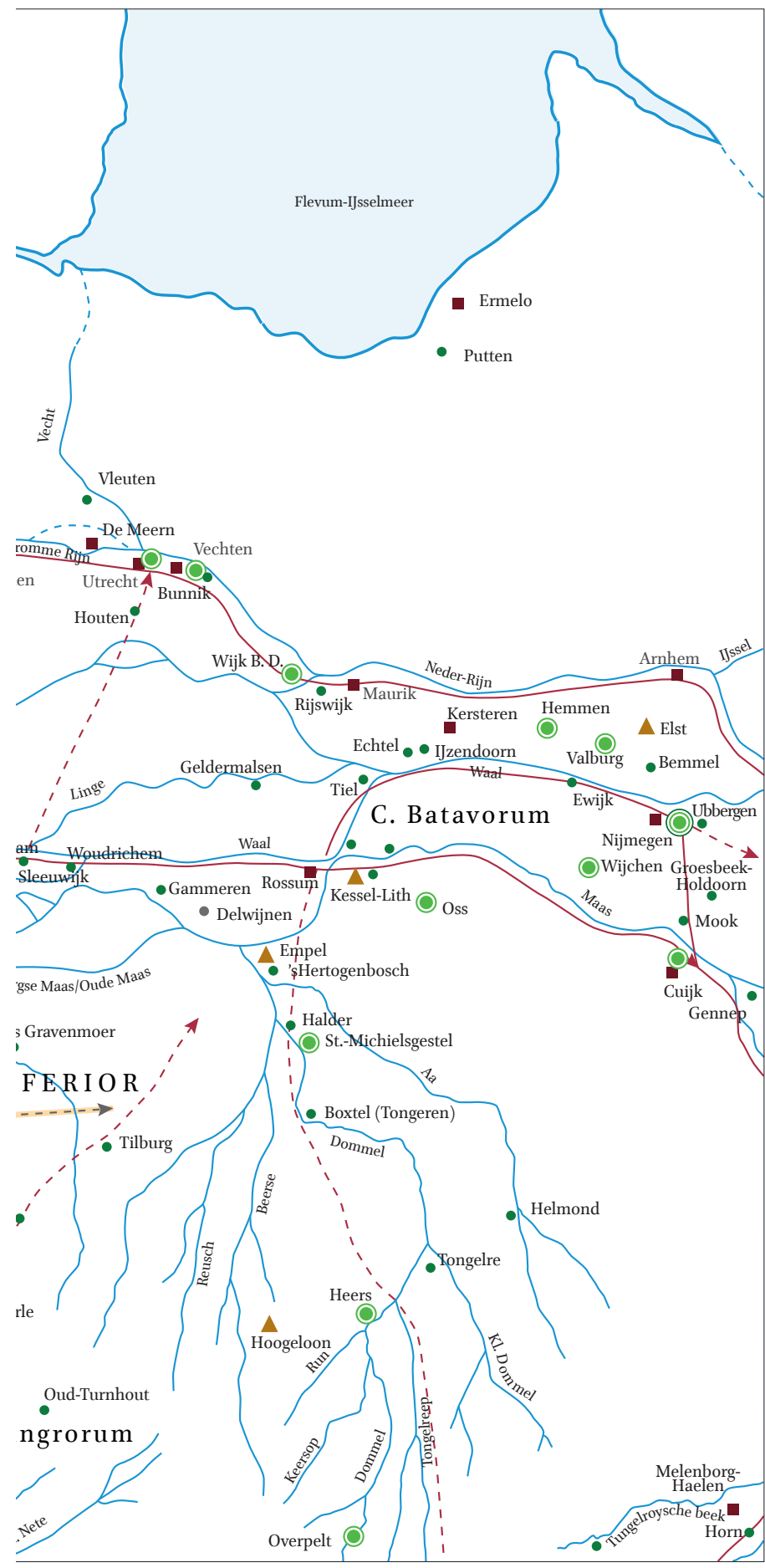

FIGURE 6.1

Map of the region discussed in this chapter

M.-T. AND G. RAEPSAET-

CHARLIER, N. BLOCH,

(C) CREA-PATRIMOINE, 2013 
inferred mainly from this architectural change. According to the authors, these surpluses were directed to the new urban and military markets, and led to the intensification of the monetary economy, as witnessed by the numerous "imported" objects found in rural settlements.

This article thus alters our perception of the area and raises important questions. Together with other papers from the "Sustainable Frontier" project, it contributes to a more balanced view of the Batavian territory, which was less underdeveloped than previously assumed. Nonetheless, the idea that the area experienced a significant increase in crop cultivation and yielded enough surpluses to feed the producing and part of the non-producing population is at odds with the fact that Batavians cultivated the same range of crops from the Iron Age down to Late Antiquity/Early Middle Ages (when rye was introduced). This contrasts strongly with what can be observed in more southerly regions (see the works of Véronique Zech-Matterne for northern France) and raises questions as to whether the western Lower Rhine area actually ever experienced significant agrarian changes in the Roman period.

As the latest and most comprehensive attempt at quantifying agrarian production on the Lower Rhine, the JRA paper is the obvious starting point for new research on the subject. Assessing its results appears all the more necessary that they are now taken as hard data and serve as starting points for new research projects, rather than being discussed as working hypotheses (see e.g. Finding the limits of the Limes 2012). This will be the aim of the present chapter, building on the new method for calculating the storage capacities of granaries put forward earlier in this book (see Chapter 3 in this volume) and making use of new archaeological data from the region. Although the quality of the excavations themselves is of a high standard, they generally concern only part of the settlements. It is for this reason that the 2009 paper commented on above only used the evidence from two fully excavated sites: only then is it meaningful to attempt correlations between demographics, storage capacities, and sown areas. Since then, more extensive excavations have been published, most notably in Geldermalsen "Hondersgemet" (cat. 304) and Cuijk "De Nielt" (cat. 317). Furthermore, partial excavations can still yield interesting information, e.g. on the changes in the shape and size of granaries through time. Augmenting the sample is all the more important as granaries, and wooden structures in general, are not often precisely dated in the Netherlands. Due to the sandy nature of the soils, a clear stratigraphy is often lacking and material directly associated with buildings is rare. Since some building types, particularly outbuildings such as granaries, remained unchanged from the Bronze Age to the Middle Ages, it is not possible to date them on the basis of their plan alone. This is why in Oss "Ussen", a well-excavated settlement occupied from 
the eighth century вСЕ to the third century CE, $84.15 \%$ of the 479 granaries are not dated (Schinkel 1998, 255-66; here cat. 22/311). In Wijk bij Duurstede "De Horden", one of the two sites studied in Groot et al. 2009, 61.79\% of the 89 granaries remain undated and only $26.96 \%$ of all granaries are dated to a single phase of occupation (Vos 2002, 111-12). In more recent publications, granaries tend to be distributed among occupation phases with greater confidence, on the basis of situation, orientation and vicinity to other structures (see for instance Tiel "Passewaaij": Heeren 2009, 38-48). But this is not always the case: in the excavation report from Cuijk "De Nielt", 39 of the 62 structures identified as granaries $(62.9 \%$ of the total) are left without a date (Habermehl and Renswoude $2017,854-71)$. In this paper, I have retained the chronology proposed in the original publications; still, the reader should bear in mind that many structures are not intrinsically dated and that there is a possible, even probable, margin of error that does not appear as such in our reasoning.

As the reader will have understood, I will focus on crop production, since evidence for specialization and intensification of animal husbandry is much more conclusive (see now Groot 2016). I will start by discussing the shape and size of granaries, trying to show that although larger storage facilities did appear in the second and third centuries $\mathrm{CE}$, there was no straightforward evolution from small buildings in the Iron Age to big ones in the Roman period. I will then tackle the tricky problem of their storage capacity, which has been much overestimated in previous works. In my view, it is doubtful that the emergence of bigger structures in Roman times actually points to increased agrarian production. This will lead me to advance a new hypothesis concerning the changes observed in the Batavian countryside in the first three centuries CE.

Romanizing the Granaries?

Underground silos are not found in the Rhine area, for obvious practical reasons: the water table is high and flooding frequent, making this storage method highly unsafe. For mid- to long-term storage, above-ground granaries built on wooden posts have always been the preferred method. As said previously, there is clear continuity between the Iron Age and the Roman period. Kees Schinkel $(1998,255)$ designed a typology for Oss "Ussen", that was later adapted by Vos (2002, 49-50) for Wijk bij Duurstede "De Horden". It consists of three groups and is now widely used in the Netherlands (Table 6.1).

Group 1 consists of granaries on two rows of posts (generally 4 or 6), group 2 on three rows of posts (generally 9 or 12). These first two groups are known at least from the beginning of the Iron Age in the eighth century $\mathrm{BCE}$ and are 
TABLE 6.1 Typology of granaries on post used in the Netherlands BASED ON SCHINKEL 1998 AND VOS 2002

\section{Sources}

Schinkel 1998

Vos 2002

Type 1: 2 rows of posts

4 posts

6 posts, narrow

$\begin{array}{ll}\text { IA } & 1 \mathrm{a} \\ \text { IB } & 1 \mathrm{~b} \\ \text { IC } & 1 \mathrm{~b} \\ \text { ID } & 1 \mathrm{c} \\ \text { IE } & 1 \mathrm{~d}\end{array}$

6 posts, large

$7+$ posts

$1 \mathrm{~d}$

Type 2: 3 rows of posts

9 posts

$\begin{array}{ll}\text { IIA } & 2 \mathrm{a} \\ \text { IIB } & 2 \mathrm{~b} \\ - & 2 \mathrm{c} \\ \text { IIC } & 2 \mathrm{~d} \\ - & 2 \mathrm{e}\end{array}$

Type 3: horrea

Floor on 9 posts surrounded by wall

IIIA

Floor on 12 posts surrounded by wall

IIIB

Posts in trench

(III)

Varia

found during the Roman period and beyond. Group 3 is more diverse and comprises storage structures generally referred to as horrea in the Dutch literature, i.e. large granaries with plans not known in the Iron Age, and therefore perceived and dated, most of the time with good reasons, as Roman.

The commonly accepted idea is that, during the Principate, granaries got larger, and at the same time boasted a Romanized architecture, apparently inspired by military storage buildings (Groot et al. 2009, 239 fig. 5, illustrates this idea quite clearly). This is indeed the general tendency; if one compares for instance the floor area of granaries from Oss "Ussen" from the Early Iron Age (8th- $5^{\text {th }}$ c. BCE ) to the Roman period (1st-3rd c. CE), it is very clear that granaries of $20 \mathrm{~m}^{2}$ or more only appear in the Roman period (Fig. 6.2). Evidence from other sites allows for more precision: granaries of $20 \mathrm{~m}^{2}$ appeared around the mid-first century $\mathrm{CE}$; granaries of $5 \mathrm{om}^{2}$ appeared at the end of the century only, and the biggest granaries are generally dated from the mid-second 


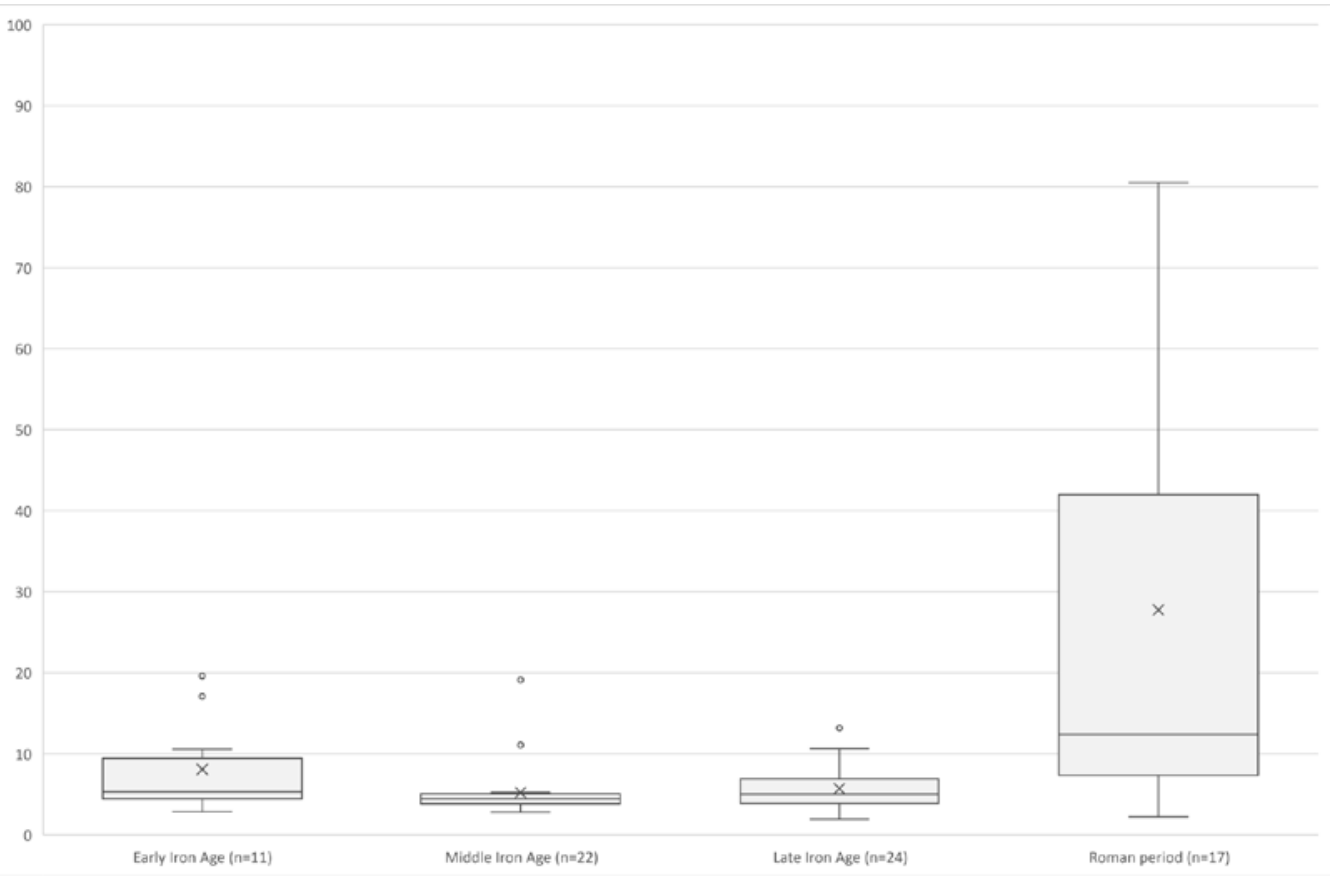

FIGURE 6.2 Boxplot of the surface in square meters of excavated granaries in Oss "Ussen". Quartile calculation includes the median. The cross indicates the mean. S. MARTIN, BASED ON DATA FROM SCHINKEL 1998

century onwards (for a general overview in northern Gaul, see Habermehl 2013, 148-52).

However, a closer look at the data shows there is no linear progression from small four-post granaries to big Roman horrea. As the authors of the paper in the $J R A$ themselves noted, large storage buildings are not to be found on every site (Groot et al. 2009, 249). For instance, in Geldermalsen "Hondersgemet", the biggest granaries from the first three centuries CE were never bigger than ca. $32.5 \mathrm{~m}^{2}$ and most of them were in the 10 to $20 \mathrm{~m}^{2}$ range characteristic of the Iron Age. Small granaries never disappeared and are found throughout the Roman period, sometimes alongside larger facilities (see e.g. for Tiel, Heeren 2009, 179-81, figs 93-95). Since they are also harder to date, their number for the Roman period is likely to be underestimated on several sites. Finally, on several sites, there is actually little to no evolution in terms of granary size and architecture, from the Iron Age to the Roman period (see e.g. Cuijk "De Nielt" or, for the first two centuries CE, Houten "Molenzoom" [cat. 307]). 
In addition, the classification of most of the bigger granaries within a single "horrea" category is problematic. In their respective typologies, Schinkel and Vos adopt differing criteria to define them. For Schinkel $(1998,255)$, a granary is a horreum when a wall surrounds the floor (see fig. 6.3, granary B11 from Tiel and fig. 6.4, granary $S_{309}$ from Oss). Vos $(2002,50)$ has two sub-types: the first comprises granaries with posts embedded in trenches, a technique generally considered as Roman, found for instance in military camps (see again fig. 6.3 and 6.4); the second is merely defined as "diversen", which is not very satisfactory. But it has the merit of making clear that, when there is no clear Roman architectural trait, it is size that acts as a criterion of Roman-ness. The case of granary 47 in Tiel "Passewaaij" is a good illustration of this (fig. 6.3): in the Dutch publication, it is defined as a horreum (Heeren 2009, 176, 311), which is translated as "Roman style granary" in the JRA paper (Groot et al. 2009, 243). But granary 47 does not fit in Schinkel's group III, nor in Vos' sub-type 3A (with posts in trenches); it is of course possible to classify it as Vos ${ }_{3} \mathrm{~B}$, but structurally it belongs to group 2, i.e. granaries on three rows of posts (see e.g. the undated granary $\mathrm{S} 455$ from Oss for a similar plan, with similar dimensions: Schinkel 1998, 258 fig. 279).

Granary 47 from Tiel "Passewaaij" clearly shows that architectural traits perceived as Roman and size do not always go hand in hand. We also know cases of granaries that would be classified as horrea according to Vos, because the supporting posts are entrenched, but which are actually very small. This is the case for instance in Zaltbommel, where five granaries correspond to Vos $3 \mathrm{~A}$ horrea: the largest has an area of $30.25 \mathrm{~m}^{2}$, three measure $16 \mathrm{~m}^{2}$ (thus within the range attested during the Iron Age) and the smallest... less than $3 \mathrm{~m}^{2}$ ! Interestingly, the smallest of the five has been dated 100-175 CE whereas the others were out of use by $150 \mathrm{CE}$ (Veldman and Blom 2010, granaries 4, 7, 12, 13, and 22; cat. 314).

What is more worrying is that granaries with entrenched posts are also known north of the Rhine, sometimes very far from the Roman frontier, for instance in Archsum, near the German border with Denmark. The structures are dated to the second century CE (Kossack, Harck, and Reichstein 1974; Kossack and Baessler 2001; cat. 300). Although Georg Kossack considers that the buildings were modelled after Roman prototypes, whether the presence of foundation trenches for posts is a marker of Romanization is doubtful, all the more so when one considers that this technique is also found in Iron Age Britain and Inner Gaul, although in this case with only two rows of posts (Guillier et al. 2015, 222, 223 fig. 37, 224 tab. 17, with earlier references). 


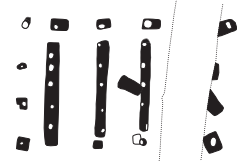

Tiel “Passewaaij”, B11

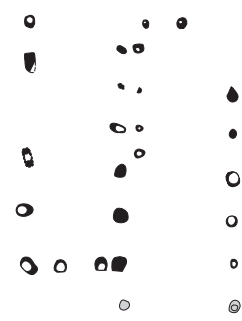

Tiel "Passewaaij”, B47

The Hague "Uithofslaan", 3002

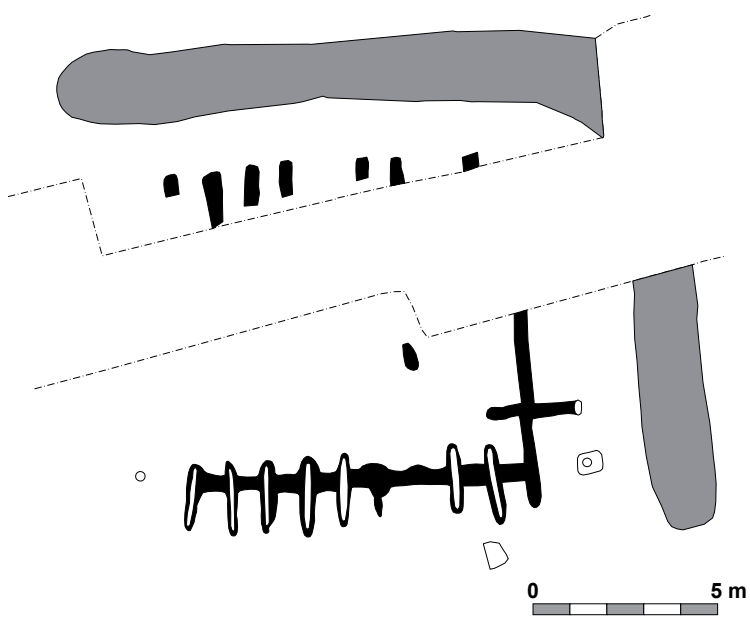

FIGURE 6.3

Granaries classified as "horrea" in the typologies from Schinkel and Vos. All plans at the same scale FOR TIEL, HEEREN 2009 , 179 FIG. 93 AND 180 FIG. 94; FOR THE HAGUE, PAVLOVIC 2011, 76 FIG. 3.16, WITH MODIFICATIONS

\section{$2 \quad$ Calculating Storage Capacities}

To sum up, without denying that some transformations in shape and size are obviously to be found in granaries from the Roman period, it must be stressed that there is neither a linear evolution from small to large storage facilities, nor towards a more Roman architecture. To go further, it is necessary to take into account all granaries and to investigate the storage capacities of the buildings in more detail. As written earlier in this book, however difficult it is, we have no other way of calculating the extent of potential surpluses.

The calculations in the $J R A$ article are simple: for a given occupation period, the area of all structures identified as granaries is multiplied by the density of stored cereals (hulled grain is assumed, which is consistent with archaeologi- 
cal finds). ${ }^{2}$ Of course, the authors are well aware that there is no straightforward relation between the floor area of a granary and how much could be stored in it (see Part I in this volume). They insist mainly on the lifespan of wooden granaries which, at an estimated 15 to 25 years, is less than the estimated lifespan of houses.

However, the proposed calculations are problematic. First of all, the density proposed for grain, $280 \mathrm{~kg} / \mathrm{m}^{3}$, is at odds with every other estimate found in the literature. It appears to stem from measurements made by Kooistra during her doctoral research, which gave a density of $367 \mathrm{~kg} / \mathrm{m}^{3}$ for spelt in chaff and 272 $\mathrm{kg} / \mathrm{m}^{3}$ for emmer in chaff, both after a single threshing (Kooistra 1996, 98 and 318, and not 66-8 as indicated in Groot et al. 2009, 235 note 22). These are very low values, in particular for emmer: P. Ouzoulias $(2006,174)$ gives a mean density of $46 \mathrm{ogg} / \mathrm{m}^{3}$ for hulled emmer. True, this last figure is quite high compared to the ranges found in other publications (Saunders 1904: $375^{-474} \mathrm{~kg} / \mathrm{m}^{3}$; Stallknecht, Gilbertson, and Ranney 1996: $\left.360-440 \mathrm{~kg} / \mathrm{m}^{3}\right)$; but even the lowest figures are much higher than Kooistra's measurements, which were taken after the first threshing. Furthermore, this is considerably lower than the density of barley, which probably constituted a large part of the stored crop (Plin., Nat. 18.62 gives a density of $560 \mathrm{~kg} / \mathrm{m}^{3}$ for hulled barley, consistent with modern data: Ouzoulias 2006, 176; Charrondiere, Haytowitz, and Stadlmayr 2015, 9).

Second, the difference between the total surface area and the usable surface area is not taken into account, notwithstanding the fact that one half of the largest storage facility in their corpus, granary 47 from Tiel "Passewaaij", seems to have been empty when the building burnt (Kooistra and Heeren 2007: grain was only found in the postholes of the southern half of the structure). This probably accounts for the excess of storage space they reconstruct. Indeed, they compare the results of their calculations with the reconstructed grain requirements of the inhabitants. The reconstructed quantity of stored grain is generally much greater than the reconstructed quantity of required grain (Groot et al. 2009, 242 table 1). So much so, in fact, that the granary cannot have been used for crop storage only, as the authors themselves note. They therefore propose that granaries were also used to store other products, such as animal fodder (Groot et al. 2009, 249. For the storage of fodder, see also Groot and Kooistra 2009; Vossen and Groot 2009). However, the idea that fodder accounted for some of the extra storage space is not supported by the article's own data. Indeed, the main use of fodder is to feed stabulated livestock. If the

2 For the western Lower Rhine, there has been one attempt by Otto Brinkkemper at calculating storage capacities before Groot et al. 2009, limited to two granaries belonging to Schinkel's group III (Brinkkemper 1993, 149-50; Brinkkemper et al. 1995, 163). Although it is cited in subsequent work, as a whole the method has not been applied to other sites and I will therefore not discuss it here. 
growth of storage space corresponded to growing quantities of fodder, we would thus expect a similar growth in the number of stalls. However, stabulation space remains constant through the centuries, making extra storage of fodder unlikely (Groot et al. 2009, 242 table 1; calculation of stabulation space is explained at 235).

Since no significant change has been detected in the archaeobotanical records, whether in crop types or in the ratios between the various cultivated plants, a solution to the problem is not likely to come from this direction.

One way out is to revise the calculations and try to rectify some of the issues identified above, using the model proposed in Chapter 3 of this book. I will use hulled barley as the main crop, with a density of $560 \mathrm{~kg} / \mathrm{m}^{3}$. This is denser than hulled wheat, and barley chaff appears to be lighter than that of emmer: in this respect, the following calculations should be taken as rather high estimates (Brinkkemper 1993, 149, for the proportion of chaff to grain: after a first threshing, chaff is estimated at only $1 \%$ of the total weight [note that Brinkkemper uses much higher densities]. For spikelets before threshing, we should probably assume 10 to $20 \%$ of the total weight). Usable surface area will be equated with $70 \%$ of the total area, with a storage height of $30 \mathrm{~cm}$; this last figure is rather low, but is attested in Amiens "ZAC Cathédrale" (cat. 250) for hulled spelt (see Chapter 3). No attempt is made here to quantify post-harvest losses. The sample of sites has been expanded to include data not discussed in Groot et al. 2009. Furthermore, I have used occupation periods as defined in the original publications, rather than half-centuries as in the paper; this makes it more difficult to study Wijk bij Duurstede "De Horden", since most granaries are dated to two phases or not dated at all (this is the case, for instance, of the larger granaries).

The newly reconstructed storage space is compared with the original grain requirements proposed in the article (Groot et al. 2009, 234-35: a family of 6.5 persons per house, needing $1178.6 \mathrm{~kg}$ of grain each year to meet $70 \%$ of its protein requirements; the reserve is assumed to be $50 \%$ of the grain needed for consumption, and sowing-seed, $20 \%$ of consumption + reserve). Delving more precisely into these matters may have been useful, but seemed unnecessary here. It must be kept in mind that we are only dealing with estimates; although it does not appear in the figures, the reader should remember the margin of error might be substantial. As a benchmark against which to evaluate the relative value of various storage capacity calculations, the estimated grain requirements as published in 2009 are therefore good enough. Furthermore, it will be easier to show that the storage capacities were overestimated in 2009 by using the same grain requirements as in the original paper (Table 6.2).

Although the sample remains small, some tendencies are nevertheless clear. In Geldermalsen "Hondersgemet" and Tiel "Passewaaij", the relation between 
TABLE 6.2 Ratio between needed and available storage capacity on various sites from the western Lower Rhine region (for calculation method and sources, see text).

Site

Phase

TPQ

TAQ

N houses

\begin{tabular}{|c|c|c|c|c|}
\hline \multirow[t]{2}{*}{ Cuijk “De Nielt" } & $\mathrm{F}$ & 200 & 270 & 4 \\
\hline & $\mathrm{J}$ & 80 & 130 & 5 \\
\hline \multirow{5}{*}{ Geldermalsen "Hondersgemet" } & 1 & $200 \mathrm{BCE}$ & 5 ВСЕ & 3 \\
\hline & 2 & $50 \mathrm{BCE}$ & $5^{0}$ & 5 \\
\hline & 3 & $5^{\circ}$ & 120 & 5 \\
\hline & 4 & 120 & 270 & 5 \\
\hline & 5 & 270 & $35^{\circ}$ & 1 \\
\hline \multirow[t]{2}{*}{ Groesbeek "Hüsenhoff” } & 1 & 175 & 225 & 1 \\
\hline & 2 & 225 & $250(270 ?)$ & 1 \\
\hline \multirow[t]{3}{*}{ Houten “Molenzoom” } & 1 & 20 & 50 & 1 \\
\hline & 5 & 140 & 170 & 1 \\
\hline & 6 & 170 & 200 & 1 \\
\hline \multirow[t]{3}{*}{ Houten “Terrein 8A" } & 1 & 1 & $40 / 50$ & 2 \\
\hline & 2 & $40 / 5^{0}$ & $80 / 90$ & 2 \\
\hline & 3 to 5 & $80 / 90$ & 200 & 2 \\
\hline \multirow[t]{4}{*}{ Rijswijk “De Bult” } & IC & 90 & 120 & 2 \\
\hline & Id & 120 & $15^{0}$ & 3,5 \\
\hline & II & $15^{0}$ & 210 & 3,5 \\
\hline & IIIa & 210 & 240 & 3,5 \\
\hline \multirow[t]{3}{*}{ The Hague "Uithofslaan" } & 1 and 2 & $6 o$ & 120 & 4 \\
\hline & & 120 & $15^{0}$ & 3 \\
\hline & 4 and $5^{*}$ & $15^{0}$ & 210 & 2 \\
\hline \multirow[t]{6}{*}{ Tiel "Passewaaij” } & 2 & 50 ВСЕ & $5^{0}$ & 4 \\
\hline & 3 & 40 & $15^{0}$ & 9 \\
\hline & $4^{* * *}$ & $15^{0}$ & 220 & 5 \\
\hline & 5 & 210 & 240 & 2 \\
\hline & 6 & 240 & 270 & 1 \\
\hline & 7 & 270 & $35^{\circ}$ & 2 \\
\hline \multirow[t]{2}{*}{ Wijk bij Duurstede "De Horden" } & 1 & 1 & $5^{\circ}$ & 8 \\
\hline & 2 & $5^{0}$ & 70 & 8 \\
\hline \multirow[t]{2}{*}{ Zaltbommel “De Wildemann” } & $\mathrm{A}_{1}$ & 1 & 50 & 2 \\
\hline & B & 75 & $15^{0}$ & 2,00 \\
\hline
\end{tabular}


$\mathrm{Nb} \quad$ Storage capacity

inhabitants needed in $\mathrm{m}^{2}$ (calcula- needed in $\mathrm{m}^{2}$ tions according to

Groot et al. 2009)
Storage capacity

(calculations accord- in $\mathbf{m}^{2}$ ing to this chapter)
Storage space Ratio storage

available

capacity

available/

needed
26

32,5

19,5

32,5

32,5

32,5

6,5

6,5

6,5

6,5

6,5

6,5

$1310,5^{2}$

13

13

13

22,75

22,75

22,75

26

19,5

13

26

58,5

32,5

13

6,5

13

$$
5^{2}
$$

52

13

13,00

\section{1,05}

26,31

15,78

26,31

26,31

26,31

5,26

5,26

5,26

5,26

5,26

5,26

10,52

10,52

$10,5^{2}$

10,52

18,42

18,42

18,42

$$
\text { 21,05 }
$$

15,78

$10,5^{2}$

21,05

47,35

26,31

$10,5^{2}$

5,26

$10,5^{2}$

\section{2,09}

42,09

$10,5^{2}$

$10,5^{2}$

\section{0,11}

62,64

$37,5^{8}$

62,64

62,64

62,64

12,53

12,53

12,53

12,53

12,53

12,53

25,06

25,06

25,06

25,06

43,85

43,85

43,85

50,11

37,58

25,06

$5^{0,11}$

112,75

62,64

25,06

12,53

25,06

100,22

100,22

25,06

25,06
20,19

29,00

156,07

56 ,оo

73,38

92,60

97,85

$5^{1,92}$

190,26

17,32

14,81

11,76

10,80

9,61

22,75

11,03

31,50

93,50

64,66

0,40

0,46

4,15

o,89

1,17

1,48

7,81

4,14

15,19

1,38

1,18

o,94

0,43

0,38

0,91

0,44

0,72

2,13

1,47

66,45

28,75

1,33

87,40

0,76

3,49

3,86

193,49

1,22

137,86

106,92

1,71

28,72

1,15

4,40

0,35

9,36

0,37

74,70

0,75

127,45

1,27

26,30

1,05

$99,25 \quad 3,96$ 
available and required storage space is of 4:1 (in favour of the former) during the first phase, which corresponds to the Late Iron Age on the first site, and to the period from $50 \mathrm{BCE}$ to $50 \mathrm{CE}$ on the second. This is probably due to the construction of numerous small granaries with a short lifespan, a situation that is also found in the second half of the first century CE in De Meern "Oudenrijnseweg” (Luksen-IJ tsma 2009; cat. 303). On this site, 20 granaries are associated with a single house; however, 18 are concentrated in two locations, next to or within an enclosure interpreted as a paddock, with several granaries overlapping and at least two rebuilt on the same spot. Foodstuff was probably stored in the two granaries closest to the house, clearly separate from the other ones.

In Tiel "Passewaaij" and Geldermalsen "Hondersgemet", the first century CE sees an apparent decrease in available storage capacity, which now matches required storage capacity. This ca. 1:1 relation can be observed on other sites, making it likely that the 4:1 relation from the previous period was indeed an artefact. There is little change between the first and second centuries (Houten "Molenzoom"; Tiel "Passewaaij", periods 3 and 4; Geldermalsen "Hondersgemet", periods 2 to 4; no perceptible evolution in Wijk bij Duurstede "De Horden", although the proportion of undated granaries should not be forgotten, nor in Houten "Terrein 8A" [cat. 308]; in the coastal region, see Rijswijk "De Bult", period I, with a very low ratio [cat. 25], and The Hague "Uithofslaan", periods 1 and 2 [cat. 302]). Some sites do see an increase in the second century, but given the margin of error, it might not be significant. It is only in the last phases, at the end of the second or during the third century, that available space greatly exceeds required space (Groesbeek "Hüsenhoff", period 1 and mostly period 2 [cat. 305]; a similar evolution is seen in the coastal region in Rijswijk "De Bult", periods II and III, and The Hague "Uithofslaan", periods 4 and 5; in The Hague "Wateringsveld", the largest granary [structure no. 112] is dated to the latest period). This change is limited to a number of sites (in the same period, available space is stable then decreases markedly in Tiel "Passewaaij", periods 4 to 7 ; in Geldermalsen "Hondersgemet", the increase is only perceptible in period 5 , which constitutes a rare case of post-270 CE occupation in the region).

On the whole, then, on most sites and during most of the Roman period, there appears not to be an excess of storage space. If this new reconstruction is to be accepted, the need to explain it, by storage of fodder or other products, disappears - but so does the existence of significant surpluses. However, this conclusion is actually more in line with other studies written before or contemporaneously with Groot et al. 2009. For instance, in 1996, Kooistra wrote in her dissertation, speaking of the Kromme Rijn area: 
With such a dense population, it is hardly possible to produce more than is required. From the organic material it appeared that more was probably produced than the population needed. With regard to the foodstuffs, this production must have been of marginal importance for the nonagrarian population in the Kromme Rijn area. (Kooistra 1996, 72)

Some years earlier, Guus Lange, writing about Wijk bij Duurstede "De Horden", was even clearer: "The remains from De Horden do not allow the conclusion that the emphasis on arable farming increased. The minor importance of cereal remains in [later periods], compared to [the first period of occupation], points rather to the contrary" (Lange 1990, 140). Another important argument is that the available arable land was limited to a small part of the landscape, namely the stream ridges, which area could not be expanded (this is well demonstrated for Tiel "Passewaaij" in Groot and Kooistra 2009). One could argue for a more intensive exploitation of stream ridges, but this means a larger workforce, and the size of the settlements does not indicate any population boom (not to mention that part of the new surpluses would have fed the extra population). The intensification of production seemingly brought by the Roman conquest is not to be looked for in crop production, as Groot (2016) has shown convincingly in her latest monograph, confirming a suggestion by Kooistra $(1996,71-73)$.

A "Romance of Storage" in a Non-Villa Landscape?

If all the conclusions from the 2009 article cannot be upheld in their original form, it remains true that a gradual trend towards larger storage buildings (not necessarily correlated with an increase in the overall storage capacity) can be discerned from the mid-first century CE onwards, culminating, on some sites only, with the erection, during the second half of the second century and in the third century, of granaries (sometimes greatly) exceeding the storage space needed by the inhabitants. If this is not related to a corresponding growth in grain or fodder production and storage, how is it to be explained?

Although it did not have their favour, for lack of existing research, another hypothesis was put forward by the authors: sites with large granaries could have acted as collecting sites for a given area (Groot et al. 2009, 249). This claim is not supported so far by archaeological data, since the construction of large granaries on some sites does not correspond to a reduction in storage space at other settlements. But the underlying idea, namely that the control over agrarian products could vary between various settlements, and it may be added, 
between different houses of the same settlement, is appealing and can be substantiated by archaeological evidence.

The evolution in the shape and size of granaries must be put in perspective with contemporary changes on the western Lower Rhine. The emergence of large granaries follows the same chronological trend as the structuration of settlements with ditches. Although settlement nucleation started in the Late Iron Age, ditches were still uncommon during this period and enclosed settlements almost inexistent (Gerritsen 2003, 181-89; Arnoldussen and Jansen 2010; Mathiot 2012, who shows that the lack of enclosures does not mean settlements were not organized). Settlements enclosed by ditches become commoner around the mid-first century $\mathrm{CE}$, when the first granaries with a floor area greater than $20 \mathrm{~m}^{2}$ are attested. The largest storage buildings appear in the second and third centuries, when enclosed settlements are the norm; at this period, ditches also divide the settlements internally, and they sometimes extend into the neighbouring areas, marking fields and other boundaries (Heeren 2009, 241-50; Vos 2009, 104-16, focused on Wijk bij Duurstede; on Oss in the Roman period: Wesselingh 2000, Jansen and As 2012; for the coastal region, Londen 2006, 183-221). Whether the ditch systems are the result of direct Roman intervention or not will not be discussed here, for it would take us too far. But scholars agree that ditches and enclosures, in addition to practical uses for irrigation or drainage, reflect changes in land management and perhaps ownership, and also have a symbolic meaning (particularly for ditches inside the settlements).

Indeed the development of ditches generally goes hand in hand with growing signs of social distinction inside the settlements, with one (sometimes more) house(s) clearly assuming more importance. In the Batavian area, they often take the form of the so-called "porticus-houses", i.e. traditional houses with a portico on one or more sides. The interpretation of these porticushouses is much debated: according to Vos, the portico is an influence from the military sphere, whereas Harry van Enckevort sees them as a local type of villa (Vos 2009, 237-51, summarized in 2015, 453-54; Enckevort 2012, 281-87; see also Groot 2011 for links between porticus-houses and specialization in horse breeding). But everyone agrees that they were special houses, very likely the seat of the leading individual or family of the settlement (see Jansen and Fokkens 2010 for the porticus-houses as Herrenhöfe). Porticus-houses are not attested in the coastal area but similar tendencies are to be found; in Rijswijk "De Bult", for instance, the principal house was rebuilt in stone on the same spot during the second century, a clear sign of stability and continuity (Bloemers 1978: house 17 was built in period Id, replaced by house 18 in period IIa; during period IIb, 


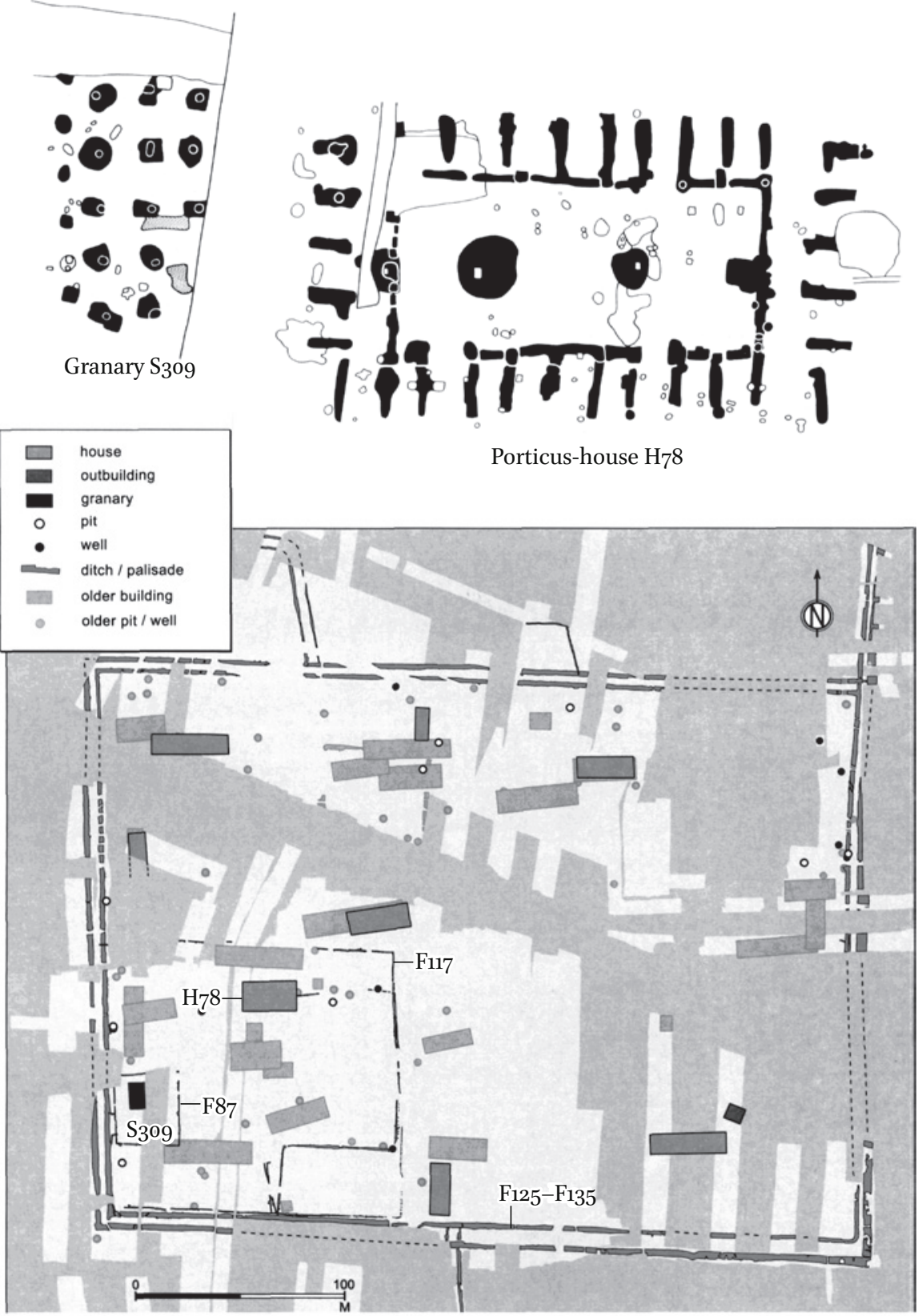

FIGURE 6.4 Oss "Westerveld", phase 4 (70-125 CE). Association between porticus-house $\mathrm{H}_{7} 8$ and large granary S 309 WESSELINGH 2000, 83 FIG. 82A, 113 FIG. 113C, AND 165 FIG. 190, WITH MODIFICATIONS 
house 19 was built with a stone cellar; during the third century, i.e. periods IIIa/ IIIb, house 19 was rebuilt with stone foundations).

There are a few cases where the link between special houses and large granaries is well attested. One of the best examples probably comes from phase 4 of the settlement of Oss "Westerveld", dated between 70 and $125 \mathrm{CE}$ (Fig. 6.4). Inside the big square ditch that encloses the whole settlement ( $\left.\mathrm{F}_{125}-\mathrm{F}_{135}\right)$, is another smaller enclosure (F117) around a porticus-house ( $\left.\mathrm{H}_{78}\right)$. Inside this smaller enclosure is yet another one ( $\mathrm{F} 87$ ), with a granary inside ( $\left.\mathrm{S}_{309}\right)$. In addition to its architecture, the porticus-house $\mathrm{H}_{7} 8$ is singled out as special by a variety of finds: two keys, two of the three coins found on the whole settlement, most of the iron and bronze objects of the settlement, a fair share of the glass vessels, and a large concentration of tiles (Wesselingh 2000, 71-169 and 214-21). The granary is obviously too large for just one house: at $80.5 \mathrm{~m}^{2}$, it is the largest of the 479 storage buildings, although house $\mathrm{H}_{7} 8$ is far from being the largest (Schinkel 1998, 250-51 for a catalogue of houses, 262-66 for granaries; granary $S_{309}$ is a horreum belonging to his type IIIb). Do we have to imagine that its use was effectively restricted to this one house, even if it was not used to its full capacity? Or did the dwellers in house $\mathrm{H}_{7} 8$ control and store produce harvested by the other inhabitants of the settlement? To a certain extent, both hypotheses are probably true.

Contemporary with Oss "Westerveld", two settlements from Houten "Doornkade" [cat. 306] and Houten "Tiellandt" offer the same association between horreum and porticus-house. In "Tiellandt", the area is notable for the discovery of stamped tiles and of an inscribed stone altar, one of the only two stone inscriptions found in the region of Houten (Vos 2009, 118-27 for Doornkade, 133-41 for Tiellandt). In Risjwijk "De Bult", in the second half of the second century, a large horreum (no. 26) is close to the principal house (no. 19); although it is not in the same enclosure, it is partially fenced off from the closest house (Bloemers 1978: during the first half of the third century, granary 26 is replaced by granary 27 . Both storage buildings are close to structures 5 and 6 , interpreted by Bloemers as temples. But some scholars interpret building 5 as a storage facility rather than a temple; see Habermehl 2013 with previous literature. For some reason, the identification of building 6 is not discussed). The same situation occurs nearby in The Hague "Uithofslaan" during period $4\left(15^{0}-\right.$ $180 \mathrm{CE}$ ) where two buildings interpreted as storage facilities (horrea 3002 and 3003) are enclosed by a ditch inside a wider enclosure, with house 1003 lying inbetween (Pavlovic 2011, 371 fig. 11.6 for an overview of the settlement during period 4. It should be noted that the plan of building 3002 is quite puzzling. The only comparison known to the author of the report comes from a very limited excavation and does not allow for a positive identification of the building's function: Heeringen, Lauwerier, and Velde 1998, 23-25). 
This development is not restricted to the western Lower Rhine region. In the neighbouring civitas of the Menapians (corresponding roughly to modern-day West-Flanders), Wim De Clercq has shown that granaries are part of what he calls "a socially constructed spatial layout displaying a successful harvest and hence the prosperity of the family" (De Clercq 2011, 242), which is particularly clear on the site of Bruges "Refuge" (cat. 301). This settlement is organized along an axial perspective, not dissimilar to the one found on villae, and granaries are clustered around the main house located at the end of the courtyard (De Clercq 2009, 225-28, 2011, 240-45. For axial villae, see Ferdière et al. 2010; Roymans and Habermehl 2011). This is all the more interesting since soils are poorer than in the Meuse-Rhine delta and possibilities of surpluses even lower. Moreover, the same development can be studied in the Gallic "villa landscape": for Northern Gaul and the Rhine area, this has been made very clear by the comparative and diachronic study of Diederick Habermehl (2013, 153-55).

On the basis of the archaeological evidence presented above, one gets the impression that the increase in size of granaries is the sign of increased power, that could have rested on an increased control over crop production and storage in the settlement. This calls to mind remarks made by Nicholas Purcell about Italian villae. Purcell famously wrote of "villae and the romance of storage", underlining how visibly storage facilities (granaries but also cisterns) were displayed, and Astrid van Oyen has recently explored the theme further, speaking of "conspicuous production" (Purcell 1995; Oyen 2015). Although the latter may underestimate the impact of technological and economic factors in designing a storage building, they both stress rightly that this was in part a cultural choice and not only an economic necessity.

Of course, the situation of the Italian countryside cannot be transposed as such to the Low Countries. But recent studies may have put too much emphasis on the specificity of the Batavian area, and more generally of the non-villa landscapes. For instance, H. van Enckevort has argued in his dissertation that settlements with porticus-houses and other non-indigenous features should actually be interpreted in the light of contemporary villae, of which they could be a local variety (Enckevort 2012, 281-90). Indeed, one could argue that some of the changes observed in rural settlements are linked to the process of municipalization that shaped the Batavian civitas from the Augustan period onwards. By municipalization, we mean the process by which communities were integrated into the Roman world, by being given the status of civitas and the institutions that went with it and that tended, with time, to closely resemble Roman institutions (see Dondin-Payre and Raepsaet-Charlier 1999 for a thorough study of the topic). It must be stressed that, even if Tacitus (Germ. 29.2) speaks of the antiqua societas which united them with Rome and dispensed them from paying normal taxes in the first century CE, Batavians were 
municipalized exactly like the rest of the provinces of Gaul and Germany. They were probably organized as a civitas in the last years of the first century BCE, when Augustus created the province of Germania at the beginning or after the successful campaigns of Drusus (see Faoro 2015 with previous literature; the idea was already put forward explicitly in Wightman 1985, 55). The ara Ubiorum, was built at the same time in Cologne for the provincial cult and it is most likely that the Batavians sent delegates. In this first phase of municipalization, the civitas retained at least partly indigenous institutions, as demonstrated by the inscription from Ruimel ( $C I L$ XIII, 8771), dated to the first half of the first century CE: it mentions a summus magistratus civitatis Batavorum, who did not have Roman citizenship and bore a Germanic name, Flaus Vihirmatis fil(ius). It was only with the creation of the new town of Ulpia Noviomagus around 100 and the granting of municipal rights probably not long afterwards, that Batavians got truly Roman institutions, with a curia of decuriones, from which magistrates were chosen each year (epigraphic data are compiled in RaepsaetCharlier 1999, 325-26; see Willems and Enckevort 2009 for an archaeological and historical synthesis). This gradual process of institutional Romanization certainly had an effect on Batavian society. Not everybody could be part of the ruling body of the civitas and, particularly after it became a municipium, magistrates were chosen from a small pool of families. This reinforced the social hierarchy and it is very possible that the process was reflected in the settlements in the countryside, with enclosures, porticus-houses and larger granaries appearing in some settlements only, while others remained very much as in the Iron Age (Enckevort 2012, 279-81, suggests that the "proper" villae, presented in chap. 11 of his study, were inhabited by members of the ordo decurionum). This would also explain why porticus-houses and big granaries disappeared after the Roman period, while "traditional" granaries and houses remained more or less the same down to the Middle Ages (for house-plans through history in the Netherlands, see Lange et al. 2014. As for granaries, it is more difficult to have an idea of their aspect based solely on the number of supporting posts; it is clear, however, that 4-post granaries remained the commonest type well after the Roman period: see e.g. Habermehl and Renswoude 2017 for Cuijk "De Nielt", with clear continuity from the Bronze Age to the Middle Ages). Porticushouses and so-called horrea were typical of a particular socio-economic situation and vanished with it.

What, then, was the economic significance of large granaries in the Batavian area? If the arguments presented above hold water, these granaries should not be taken as indicators of surplus grain production. The Roman conquest has no discernable impact on the kind and the proportions of crop species produced in the area, and the shortage of arable land in the western Lower Rhine 
region makes any significant increase in production unlikely. The integration into the Roman empire did have an effect on agrarian production, but it was limited to animal husbandry. In this domain, archaeological evidence for specialization and surplus production is much more solid and convincing. Furthermore, animal husbandry is much better suited to the regional landscape. Additionally, it requires less labour than crop production, which is again consistent with the reconstructed demographics of the region.

On another level, the study carried out in this chapter has also proved interesting in highlighting some of the assumptions underpinning previous research on the subject. Once again, the link between Romans, the market economy and economic growth is patent. In the article commented on at length in this chapter, the only way considered for disposing of agrarian surplus is the market. Neither taxes in kind nor special levies are evoked. Furthermore, the idea that surpluses were produced during the Roman period has such a hold that the problem of land availability, well discussed in Laura Kooistra's previous research, is not raised.

Besides, it is clear that the Batavian civitas was not as special as some works make it appear. The fact that on the one hand, it is rather extensively mentioned by Tacitus, in comparison with other civitates, and that on the other hand, it is mainly studied by Dutch scholars, whose work is largely ignored abroad, even when published in another language than Dutch, has led to its uniqueness being overestimated. This is not to deny that it did have some specific traits; but when compared with other regions from the Three Gauls and the Germanies, it becomes clear that Batavians experienced the same overall change in municipalization, town planning or architectural development. In the countryside, changes became visible in the second half of the first century $\mathrm{CE}$, with the first porticus-houses, and a few rare villae around Nijmegen, at the end of the century, followed by a growing demarcation of land by ditches and increased monumentalization (although very limited by Roman standards) in the second and third centuries: all in all, this is not very different from what happened elsewhere.

This last remark leads to a final question: if the interpretation of granaries in a non-villa landscape put forward in this chapter has some truth to it, could it not be applied to the villa landscapes? Should not the monumentalization of granaries in Inner Gaul or in Upper Germany be read along the same lines? And if so, how should we interpret the relation between their increased capacity and a supposed increase in productivity? 